\title{
A WORKING PROFILE: The changing face of professional archaeology in Australia
}

\author{
Sean Ulm ${ }^{1}$, Geraldine Mate ${ }^{1,2}$, Cameo Dalley ${ }^{3}$ and Stephen Nichols ${ }^{1}$
}

\begin{abstract}
Results from comprehensive surveys of Australian professional archaeologists undertaken in 2005 and 2010 are considered in the context of disciplinary trends, focusing on changes in access and participation, archaeological workplaces, qualifications and skill gaps. Strong growth is demonstrated in the professional archaeology sector between 2005 and 2010, showing substantial restructuring in the last five years, with an increase in Indigenous archaeology and a corresponding decrease in other subfields, especially historical archaeology. An analysis of self-assessed skill sets and skill gaps shows that the training of many professionals continues to leave significant gaps in core skill and knowledge areas which are consistent across industry subfields.
\end{abstract}

\section{Introduction}

Professional archaeology in Australia has changed profoundly over the last four decades. A dramatic expansion of the cultural heritage management sector has occurred at the same time as significant restructuring of the university and museum sectors, and a downsizing of the government sector. Despite these changes, there are very few data documenting the basic profile of the discipline in Australia. The usefulness of earlier surveys is limited by small sample sizes, constrained geographic scope or selective employment sector focus (see Balme and Beck 1995; Beck 1994; Beck and Head 1990; Bowman and Ulm 2009; Casey et al. 1998; Colley 2003, 2004; du Cros and Smith 1993; Feary 1994; Frankel 1980; Gibbs et al. 2005; Lydon 2002; Smith and Burke 2006; Truscott and Smith 1993).

Limitations of available data were discussed at length at the 2003 Redfern National Archaeology Teaching and Learning Workshop (Colley 2004). This workshop provided the direction and framework for a coordinated national approach to archaeology teaching and learning and the origins of the Australian National Committee for Archaeology Teaching and Learning (ANCATL), now the peak body in this area. The need for baseline data about the discipline was acknowledged at the workshop as a basic requirement for informed decision-making on archaeology teaching and learning issues. This concern was represented in one of the five key resolutions of the workshop (the 'Redfern Archaeology Teaching Charter') as a commitment to gathering reliable data for benchmarking of a variety of archaeology activities (Colley 2004:201).

The 'Australian Archaeology in Profile: A Survey of Working Archaeologists' project (hereafter AAP) described herein is an ongoing attempt to contribute to this goal, with the aims of

\footnotetext{
Department of Anthropology, Archaeology and Sociology, School of Arts and Social Sciences, James Cook University, PO Box 6811, Cairns Qld 4870, Australia <sean.ulm@jcu.edu.au>

2 The Workshops Rail Museum, Queensland Museum, PO Box 2234, North Ipswich Qld 4305, Australia <geraldine.mate@qm.qld.gov.au> ${ }^{3}$ Centre for Native Title Anthropology, The Australian National University, Canberra ACT 0200, Australia <cameo.dalley@anu.edu.au>
}

(1) building a longitudinal profile of professional archaeology in Australia, and (2) defining key archaeology learning and training issues. Survey results of the first survey in 2005 were published in Ulm et al. (2005). In this paper we present the 2010 results and draw comparisons between these and the earlier 2005 data. We have largely retained the structure of the earlier paper here to facilitate comparisons.

\section{Methods}

The survey was carried out under the auspices of the ANCATL, which includes representatives from Australian universities teaching archaeology, professional associations, Indigenous groups, industry groups and public sector employers. Although it was originally intended to base the survey instrument on those employed in similar exercises in the United Kingdom (UK) (Aitchison and Edwards 2003, 2008) and US (Association Research Inc. 2005; Zeder 1997), a review demonstrated that these studies had only limited relevance to the Australian context and to the investigation of teaching and learning issues. For example, owing to the very different structure and scale of the archaeology profession in the UK, the quinquennial 'Archaeology Labour Market Intelligence' survey was directed at organisations employing archaeologists, rather than individual archaeologists, and focused on employment conditions, training, standards, union membership, leave, overtime etc. (Aitchison 1999; Aitchison and Edwards 2003, 2008). Similarly, the 1994 Society for American Archaeology census (Zeder 1997) had a strong focus on demographic information and workplace roles, rather than on archaeology teaching and learning issues.

A survey questionnaire was therefore developed, modelled loosely on the more generic questions included in UK and US surveys and the baseline data requirements of the 'Discovering the Archaeologists of Europe' project (<www.discoveringarchaeologists.eu $>$ ), as well as an Australian survey of Native Title practitioners commissioned by the National Native Title Tribunal (Martin 2004). The AAP survey instrument was designed for individuals to complete, rather than organisations, overcoming some of the limitations of organisational-level approaches identified by Aitchison and Edwards (2008:25, 162) and providing opportunities to ask more specific questions to allow the collection of fine-grained data. The questionnaire comprised four sections: demographic profile; employment information; professional activities; and, learning and training issues. In the 2010 iteration of the survey several additional questions were included to elicit further information about workplaces.

As the aim of the survey was to build a profile of professional archaeology in Australia, eligibility to complete the survey was limited to anyone who:

- Used archaeological skills in paid employment during the calendar year preceding the survey census year; and,

- Worked in Australia, or was based in Australia and worked overseas. 
With the cooperation of the major archaeological associations in Australia, the questionnaires were distributed to the individual members (i.e. not institutional) of the Australian Archaeological Association (AAA), the Australasian Society for Historical Archaeology (ASHA), the Australasian Institute for Maritime Archaeology (AIMA) and the Australian Association of Consulting Archaeologists Inc. (AACAI). In addition, the survey was widely promoted on major national and international archaeology email list-servers. The 2005 survey was distributed in hard copy with reply paid envelopes, while the 2010 survey was made available using an online survey tool (SurveyMonkey ${ }^{\circledR}$ ).

Classical archaeologists are likely to be under-represented in the respondent dataset, as they tend not to be members of archaeological associations focused on Australian archaeology and therefore were less likely to receive information about this survey or the survey conducted in 2005. We attempted to circumvent this by directly contacting classics and ancient history academics and major associations, including the Australian Archaeological Institute at Athens. We also note that AAA, ASHA and AIMA contain a large proportion of avocational and student members who may not be working in the discipline and were therefore ineligible to complete the survey. For example, in 2009 AAA had 649 individual members, including 137 students (Ash and Brady 2010). Of these, 289 AAA members completed the 2010 survey.

\section{Results}

There was a strong response rate for both surveys (2005 $n=301$; $2010 \mathrm{n}=399$ ), including an extensive range of qualitative comments, mostly focused on teaching and learning issues. Although the surveys cover many facets of the profession, the sections below focus on access and participation rates, the archaeological workplace, qualifications and experience, and skill sets and gaps. Results from 2010 are presented with comparisons drawn with the 2005 survey and the findings of previous Australian studies and some overseas surveys.

\section{Access and Participation}

Various estimates have been proposed for the size of the professional archaeological community in Australia. Hope (1992 as cited in Lydon 2002:131), for example, estimated a maximum paid community of 355, while du Cros (2002:5) estimated 470 full-time archaeologists. The current survey demonstrates that in 2009 a minimum of 399 people worked as paid archaeologists.

Although undertaken between the census periods for our 2005 and 2010 AAP surveys, results of Smith and Burke's (2006) survey of Australian academic archaeology carried out in April 2006 are instructive for assessing participation rates. Smith and Burke (2006:14-15) reported 95 archaeologists in full-time employment at Australian universities. Only 45 such individuals were represented in the 2005 AAP survey results and 71 in the 2010 results. These differences can be primarily attributed to the data collection methods. Smith and Burke (2006) confirmed staff information directly with academic managers and individual staff members, whereas the AAP survey relied on individuals voluntarily completing a questionnaire. No comparable data are available for non-academic sectors. However, if the 25-53\% under-reportage of full-time university staff is applied across all sectors of the profession, the total number of people working as paid archaeologists in and from Australia is estimated to be between 500 and 600. This accords broadly with a 2009 nonstudent membership of AAA of 512 individuals (Ash and Brady 2010).

Absolute growth of the discipline between the 2005 and 2010 census periods is more difficult to assess owing to differences in the way the survey was distributed (i.e. hard copy versus online). However, the $32.6 \%$ increase in the number of survey respondents is supported by other employment indicators outlined below. This growth is also reflected in growth in archaeological associations. Between 2004 and 2009 membership of the AAA grew by $28.2 \%$ (from 560 to 718 ) (Ash and Brady 2010; Stevens 2005).

Overall gender participation rates appear to be equitable, with $53 \%$ female respondents and $47 \%$ male (Figure 1). This is the inverse of 2005 ( $52 \%$ male, $48 \%$ female), demonstrating a continuation of the trend towards increasing participation of women noted in previous studies (see Beck 1994:211; Hope 1993:187; Ulm et al. 2005). These gender participation rates demonstrate that, compared with the US (64\% male, $36 \%$ female; Zeder 1997:9) and UK (59\% male, 41\% female; Aitchison and Edwards 2008:47), slightly more women than men are employed in archaeology in Australia. In a continuation of the trend observed in 2005, women are overrepresented in the youngest age cohort and men in the oldest. The high representation of women in younger age cohorts has also been noted in international studies (cf. Aitchison and Edwards 2008:49; Zeder 1997:11-12). Unlike the discrepancies of results between Aitchison and Edwards' (2008) closed probability survey and Everill's (2009) self-selecting individual respondents survey, the population of women in this survey reflects the gender proportion found in the two largest societies, AAA $(58.6 \%$ female, $41.4 \%$ male in 2011$)$ and ASHA (55.7\% female, $44.3 \%$ male in 2010).

Results indicate an increasingly young age profile, with $61.7 \%$ of respondents aged 45 or younger in 2010 (up from $57.2 \%$ in 2005). Beck (1994:211) linked the relatively high proportion of young people in the discipline with its 'newness', and with the limited availability of undergraduate training in archaeology before the mid-1970s (see also Colley 2002:3-4). The recent trend appears to be accentuated by the archaeology labour demands of resource extraction industries (see discussion below). This profile is further contextualised by results that show that, although over one-quarter $(28.3 \%)$ of respondents were born overseas (down from $32 \%$ in 2005) (compared with the general Australian population where in 2006 around 24\% were born overseas; Australian Bureau of Statistics 2008:209), the overseasborn dominate the workforce for those over 65 years of age (Figure 2). In comparison, in the UK only $7 \%$ of archaeologists were from outside the UK (Aitchison and Edwards 2008:53). The reduction in overseas-born practitioners may reflect the retirement of the first generation of Australian archaeologists trained overseas before the widespread availability of domestic university programmes.

The participation rates of Indigenous Australians in professional archaeology in Australia are low. Indigenous archaeologists comprised 2.3\% ( $n=7)$ of respondents in 2005 and $0.8 \%(n=3)$ in 2010 . The participation rate of $2.3 \%$ in 2005 is close to the proportion of Aboriginal and Torres Strait 


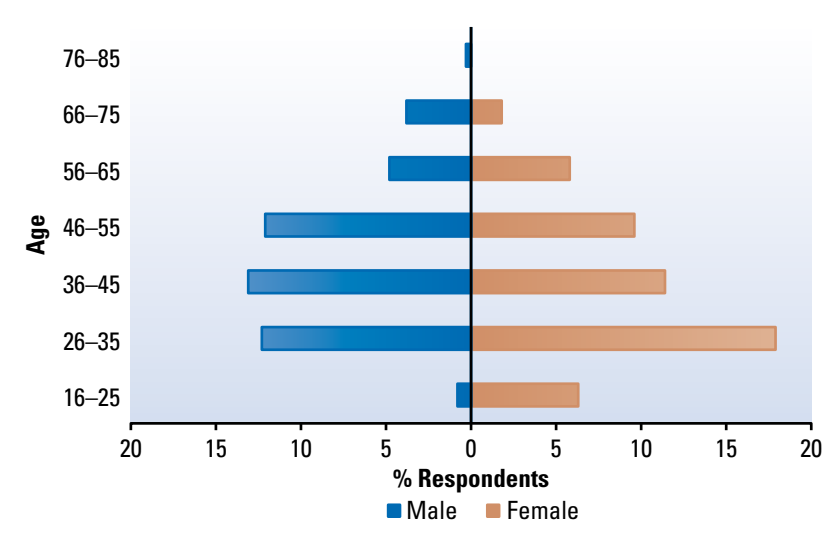

Figure 1 Respondents by age and gender $(n=396)$. Note that the number of respondents indicated on graphs does not always equal the maximum number of respondents to the survey $(n=399)$, where some questions were left unanswered or where a subset of data is employed.

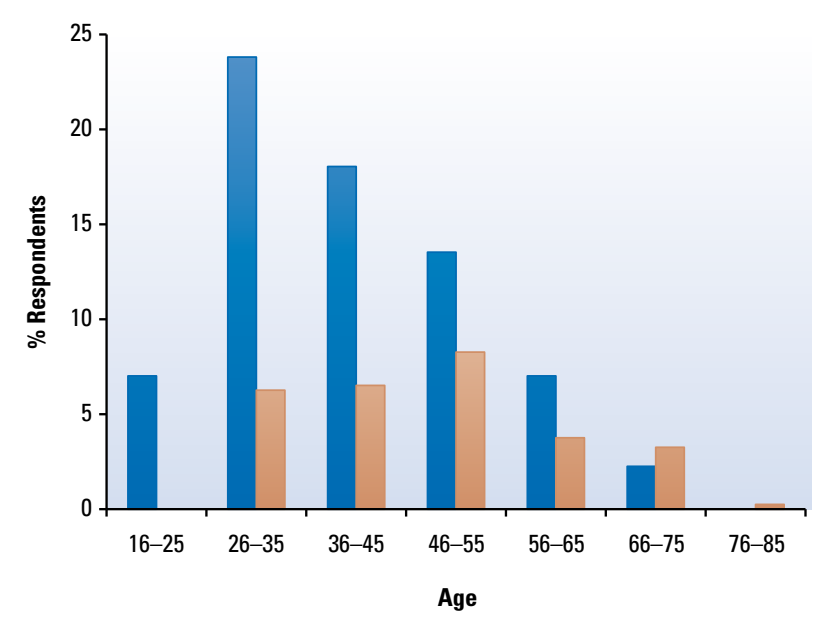

Australia Non-Australia

Figure 2 Australian-born vs non-Australian-born respondents ( $n=399)$.

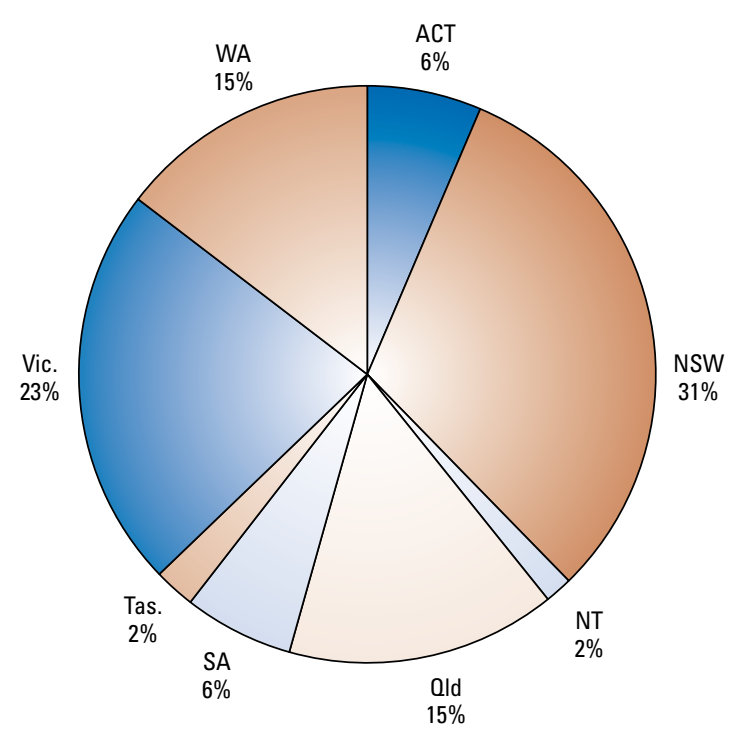

Figure 3 Respondents based in Australia by state or territory $(n=390)$.
Islander people in the broader Australian population, which was $2.5 \%$ in 2006 (Australian Bureau of Statistics 2008:196). However, the recent formation of the Australian Indigenous Archaeologists' Association, with more than 20 qualified Indigenous archaeologists (Perry 2010), suggests that Indigenous archaeologists are highly under-represented in the survey.

\section{The Archaeological Workplace}

Three-quarters of Australian archaeologists are based in the eastern mainland Australian states (Queensland [Qld], New South Wales [NSW], Australian Capital Territory [ACT] and Victoria [Vic.]) (Figure 3), with $78 \%$ of respondents based in capital cities (up from $75 \%$ in 2005), $14 \%$ in regional centres (down from 17\%), 6\% in rural areas (up from 5\%) and 2\% in remote areas (down from $3 \%$ ). There has been a decline in the number of archaeologists based in NSW (down 6\%), Qld and South Australia (SA) (both down 3\%), Tasmania (Tas.) (down $2 \%$ ) and the ACT (down 1\%), with increases of $9 \%$ in Vic. and $6 \%$ in Western Australia (WA) (see discussion below). More than $83.5 \%$ of respondents were employed in workplaces with 10 or fewer archaeologists (down from $85 \%$ in 2005) and $46.5 \%$ with five or fewer (down from 51.4\%), emphasising the small scale of work units in the discipline. There is a trend towards larger workplaces, with a decline of $3.6 \%$ in the number of workplaces with five or fewer archaeologists. Almost $71.1 \%$ were employed full-time (down from $72 \%$ ), with less than one-third (28.9\%) employed on a part-time or casual basis (up from 28\%). This trend is supported by other data showing that $66.4 \%$ of respondents worked five days or more a week (up from 65\%).

Figure 4 shows the distribution of respondents by primary subject focus and gender. The Australian archaeological workplace is conventionally divided into four main foci: Indigenous, historical, maritime and classical. Specialisations such as industrial archaeology are often viewed as a subset of one or more of these areas (Colley 2002:16). The 'other' category includes people who identified their primary subject focus as all of the above (particularly academics teaching across a broad range of fields), cultural heritage management ( $\mathrm{CHM})$, contact archaeology, prehistoric archaeology and occasional other fields, such as Egyptology and European Iron Age archaeology.

Respondents primarily engaged in Indigenous archaeology dominate $(66.4 \%$, up from $52.2 \%$ ), followed by historical archaeology (19.0\%, down from 27.8\%). The balance of respondents nominated maritime archaeology $(4.0 \%$, down from 6.6\%), classical archaeology (3.3\%) and 'other' (7.5\%) as their primary subject focus. These data denote a substantial shift in archaeological workplaces since 2005 (Ulm et al. 2005:14), with an increase of $14.2 \%$ in Indigenous archaeology and a corresponding decrease in the other subfields. Over $38 \%$ of historical archaeologists nominated Indigenous archaeology as a secondary subject focus, while more than $53 \%$ of professionals engaged in Indigenous archaeology nominated historical archaeology as a secondary subject focus, indicating a high level of fluidity across the two fields. Similarly, $62.5 \%$ of maritime archaeologists nominated historical archaeology and 50\% Indigenous archaeology as secondary subject foci. In contrast, classical archaeologists did not nominate Indigenous, historical or maritime archaeology as secondary fields, reflecting a focus on professional activities outside the Australian working context. 


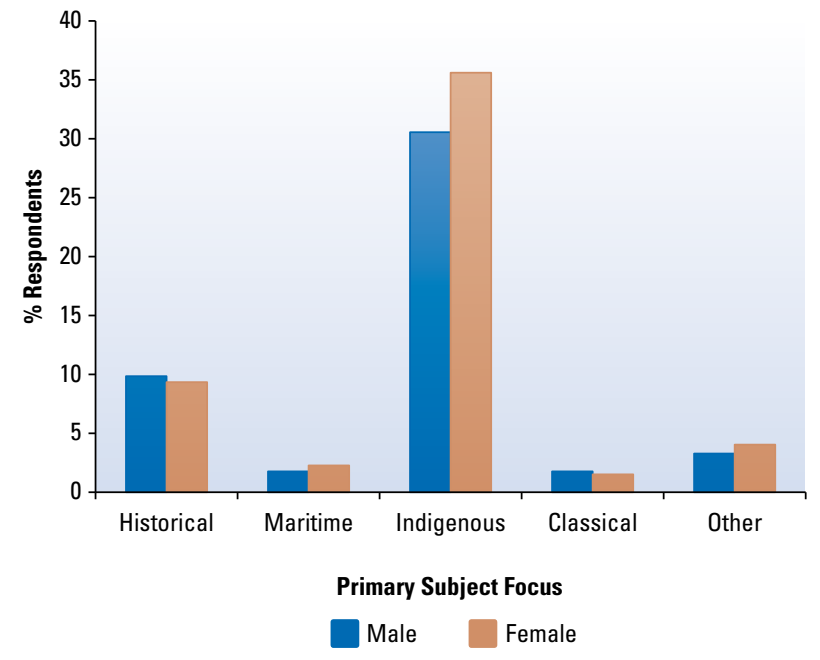

Figure 4 Distribution of respondents by primary subject focus and gender $(n=396)$.

Women are represented relatively equally across historical (48.7\%, down from $49.4 \%$ ), Indigenous (53.8\%, up from $48 \%$ ) and maritime fields (56.3\% up from $21.1 \%$ ).

Respondents across all these subfields engaged in CHM activities, with $59 \%$ of all respondents reporting that they spent at least half of their time undertaking such work. Comparative data with 2005 for this indicator are not available, as this was a new question for 2010. This trend correlates with a stated high confidence for expansion in the private sector, with $71 \%$ of respondents in that sector expecting their workplace to maintain current numbers or expand archaeological staff.

Burke and Smith (2004:xvii), among others, have noted that the main employment opportunities for archaeologists in Australia 'come from universities, museums, government departments and consulting. Figure 5 shows almost the exact reverse of this order, with $52.0 \%$ (up from $47.9 \%$ in 2005) employed in the private sector (consulting), 25.3\% (up from $25.1 \%$ ) in universities, $15.9 \%$ (down from $22.7 \%$ ) in government agencies and only $4.5 \%$ (up from $4.3 \%$ ) in museums. These data document the ongoing trend over the last two decades towards growth of the private sector and reduction or stasis in the university and museum sectors and downsizing of the cultural heritage functions of government agencies. There are slightly more men (55\%, down from $58.6 \%$ ) than women in university positions and more women (54.9\%, up from $51.1 \%$ ) in the private sector, with the gender participation rates in government-the other sector primarily concerned with CHMsimilarly distributed ( $45 \%$ male:55\% female), reflecting the overall gender distribution in the discipline (cf. Beck 1994:213; Beck and Head 1990).

Only $14.2 \%$ (up from $11.7 \%$ in 2005) of respondents indicated that the primary geographical focus of their work was outside Australia. This finding is at odds with the focus of university courses noted by Colley (2004:191), which are evenly distributed between Australian and non-Australian archaeology. This outcome is reflected in other data, such as the low ratio of fieldwork days conducted annually by all respondents overseas compared to that undertaken in Australia (1:6.5, down from 1:5.2). These findings support the mismatch identified by Colley (2004:191) between university

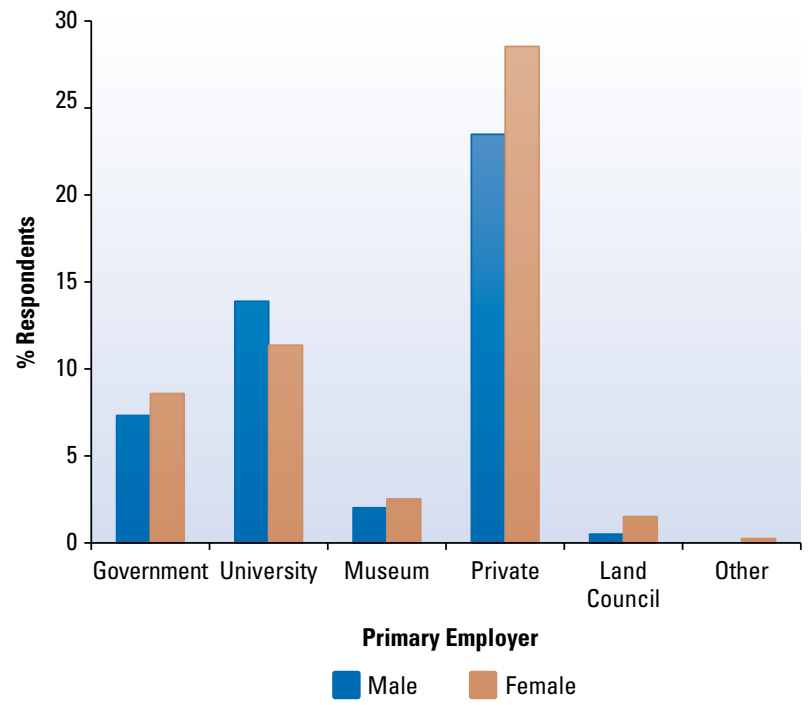

Figure 5 Distribution of respondents by primary employer and gender $(n=396)$.

archaeology curricula and the realities of the Australian archaeological workplace.

Average gross incomes for full-time archaeologists at AUD\$85,636 (up from AUD\$64,973 in 2005) remain well above the national average of AUD\$66,071 (see Australian Bureau of Statistics 2010), with over 95\% earning more than AUD $\$ 40,000$ in $2009,81.8 \%$ earning more than AUD $\$ 60,000$ and $51.3 \%$ earning above AUD $\$ 80,000$ (Figure 6). It should be noted that these average are minima, as we did not collect precise income data for respondents earning above AUD\$100,000 in 2005 and above AUD\$170,000 in 2010. However, based on these data, average full-time incomes in archaeology rose $31.8 \%$ in the 2005-09 period, well above the Australian Labour Price Index rises for the same period of $19.6 \%$ (Australian Bureau of Statistics 2009). This situation contrasts with the UK, where the average archaeologist continues to earn less than the UK average (Aitchison and Edwards 2008:71). There are, however, significant disparities in the distribution of full-time income by gender, with women earning an average of AUD\$14,321 less than men.

\section{Qualifications and Experience}

An Honours (four year) degree is often cited as the 'minimum industry standard' for professional archaeologists in Australia (e.g. Beck 2008; Beck and Balme 2005; Colley 2004:198), yet nearly $13 \%$ (down from $15 \%$ in 2005) of respondents worked in archaeology with only an undergraduate pass degree, practical experience or no academic qualifications (Figures 7 and 8). There has, however, been a significant professionalisation of the discipline between 2005 and 2010, with the percentage of respondents working in archaeology without formal university qualifications falling from $6.2 \%$ to $2.5 \%$. Maritime archaeology exhibits the highest proportion of professionals holding postgraduate degrees, reflecting the importance of taught Masters programmes in this field (Figure 8).

Ninety-seven per cent (up from 93\% in 2005) of respondents had a minimum of an undergraduate pass degree (three year degree) with archaeology as a major area of study and $87 \%$ had a minimum of a four year Honours degree (Figure 7). This result is similar to figures available from the UK $(90 \%)$, indicating that 


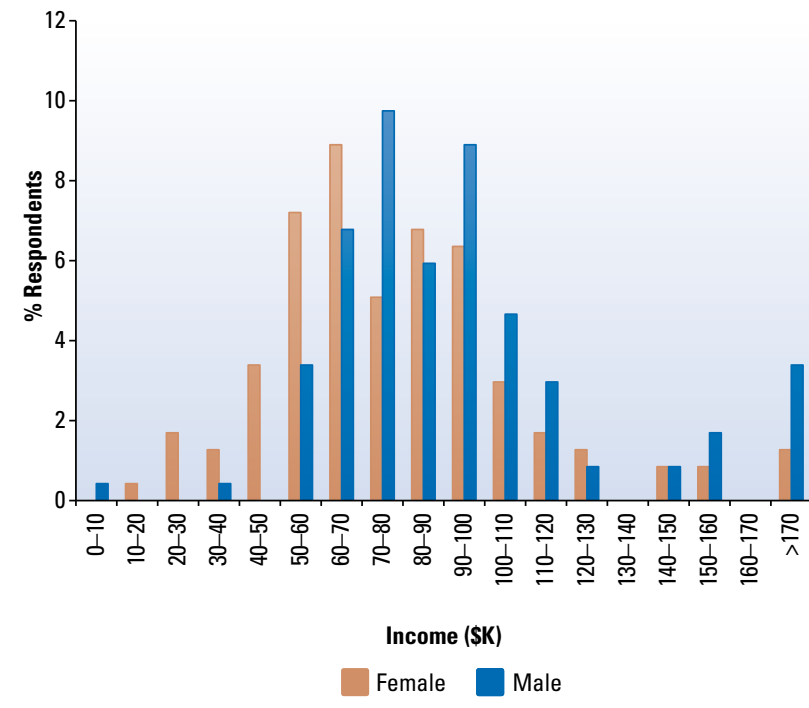

Figure 6 Full-time gross income from archaeologically-related employment during 2009 by gender $(n=283)$. Average income AUD\$85,636 (male: AUD\$92,796; female: AUD\$78,475).

archaeology is a graduate profession (Aitchison and Edwards 2003:xiii, 2008:55). Australian archaeologists compare favourably with archaeologists in the UK in terms of postgraduate degrees, with $31 \%$ (up from 30\%) of respondents in Australia holding PhDs compared with only $11 \%$ in the UK (Aitchison and Edwards 2008:55).

Not surprisingly, most archaeologists working in the university sector hold Doctorates (72.3\%, up from 70\% in 2005), with museums the next highest with $38.9 \%$, followed by government and private sectors with $25.4 \%$ and $12.5 \%$, respectively (Figure 9). Similar to 2005, there seems to be a dichotomy in museums between curatorial staff holding advanced degrees and technical staff with few formal qualifications.

The level of highest qualification of respondents is strongly correlated with income levels, with archaeologists holding postgraduate degrees dominating the income brackets above AUD $\$ 100,000$ per annum (Figure 10 and Table 1). A small but significant number of Honours graduates are in the high end salary brackets, reflecting the high number of people with Honours degrees in the private sector with greater income earning capacities than other sectors. Although many factors impact on income, this relationship might be taken as an indicator that university education is valued in the workplace, at least in terms of remuneration. The point is reinforced by the number of archaeologists undertaking study. Just over $22.6 \%$ (22.7\% in 2005) of respondents working in archaeology during 2009 were also studying, almost half of these $(48.8 \%, 47.1 \%$ in 2005) at Doctoral level.

Nearly one-quarter of respondents (23.2\%, unchanged from 2005) had completed formal academic training in archaeology outside Australia, over half of these (52.7\%, down from 55.1\%) at Research Masters or Doctoral level, indicating the important role international institutions continue to have in training archaeologists working in and from Australia at senior levels.

A final key issue in the area of qualifications and experience is the role of volunteer work. Over $93 \%$ (same as 2005) of respondents indicated that they had undertaken voluntary archaeological work. Over two-thirds $(69.1 \%$, down from $73.2 \%)$ of these had undertaken more than three months

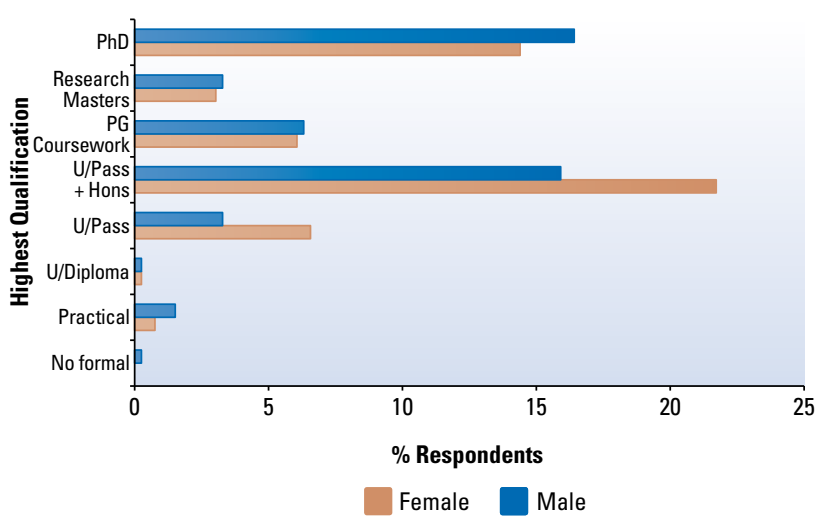

Figure 7 Highest qualification by gender ( $n=396)$.

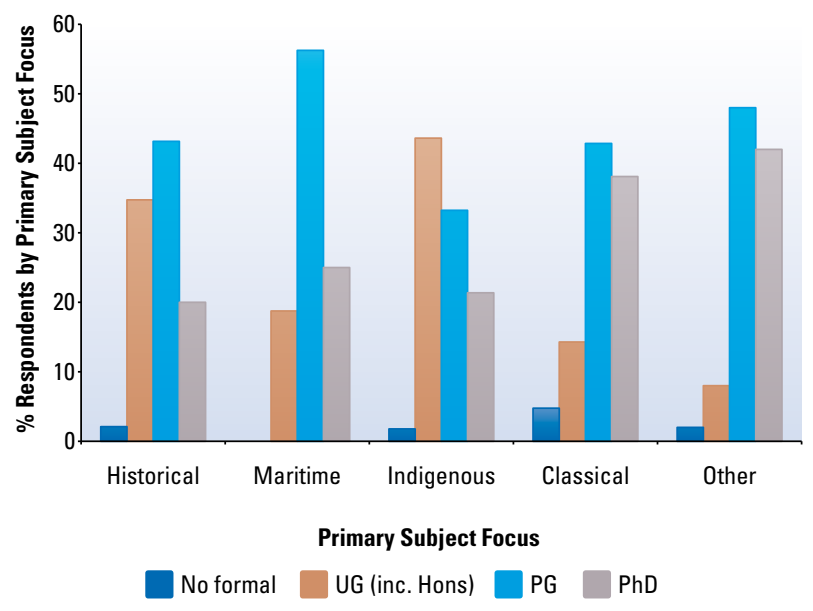

Figure 8 Highest qualification by primary subject focus, full-time only. Doctoral degrees are shown separately to indicate the proportion of postgraduate degrees which are PhDs $(n=241)$.

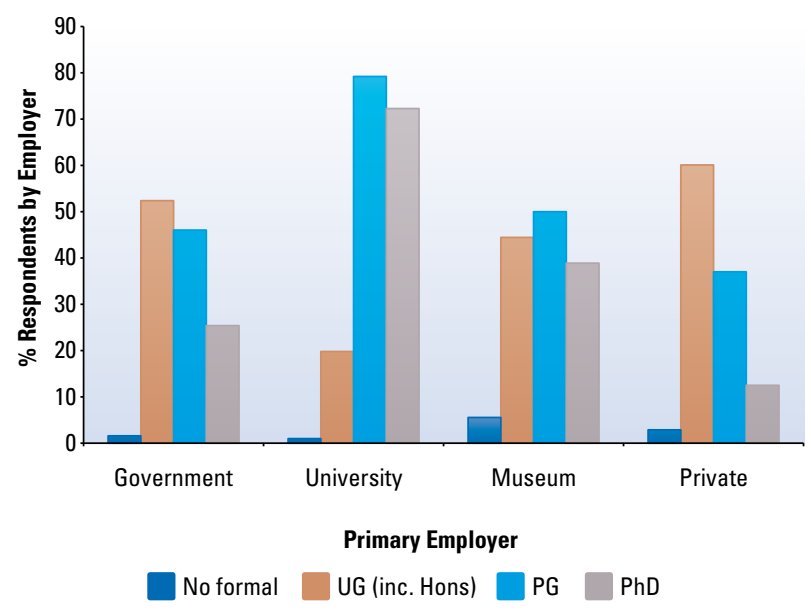

Figure 9 Highest qualification by primary employer, full-time only. Doctoral degrees are shown separately to indicate the proportion of postgraduate degrees which are $\mathrm{PhDs}(\mathrm{n}=290)$.

of voluntary work, and over one-third $(39.8 \%$, down from $42.8 \%$ ) more than six months in total over the course of their careers. These figures suggest that voluntary activity continues to play a key role in archaeology training and learning in Australia. The slight decline in the proportion of people undertaking sustained voluntary work may indicate pressure on the industry, meaning that graduates progress more quickly to full-time employment. 


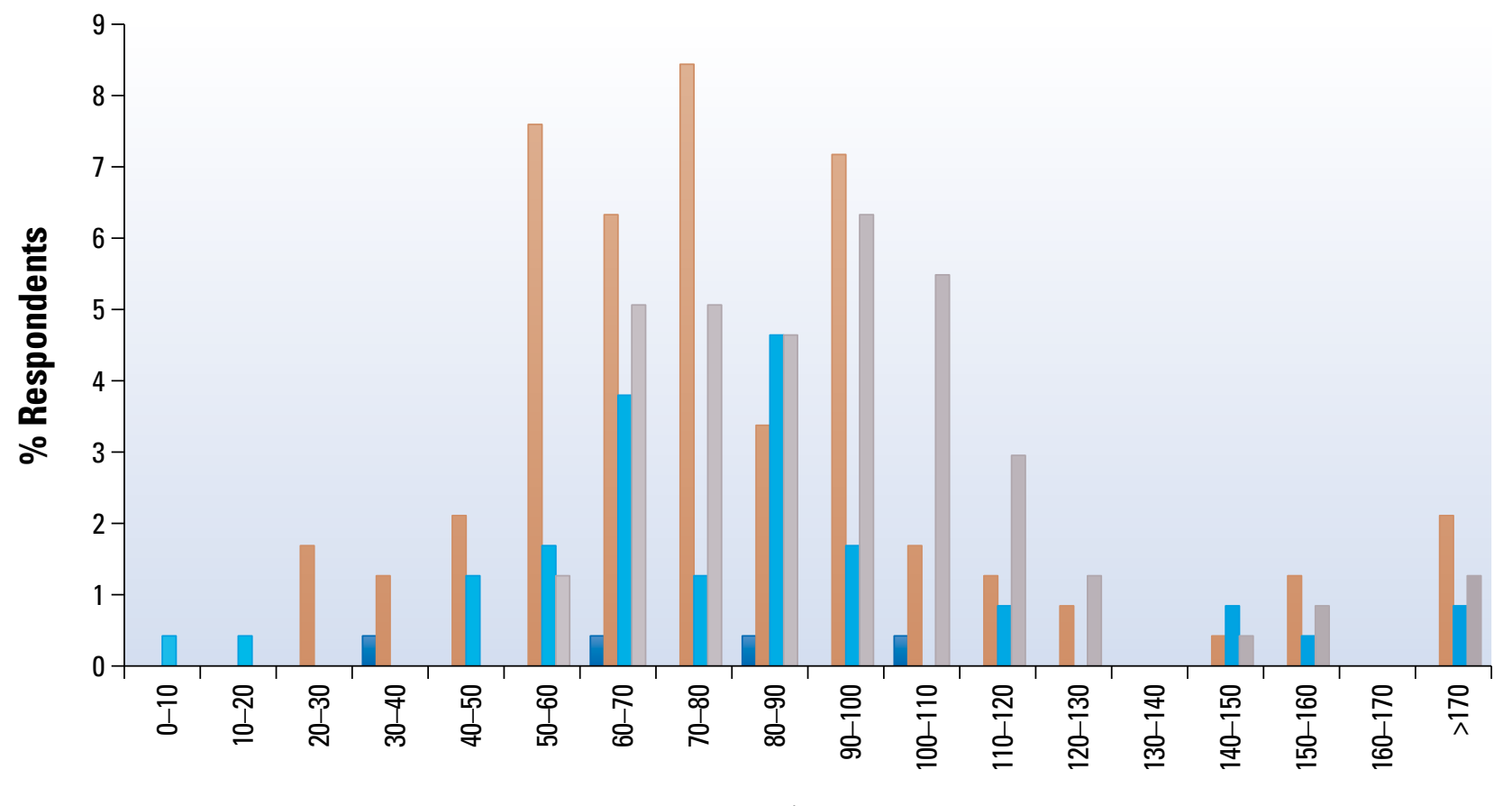

Income \$K

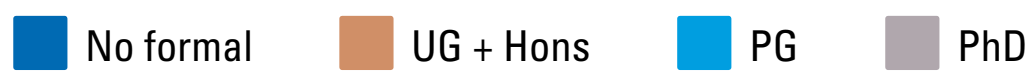

Figure 10 Relationship between highest qualification and income, full-time only. Doctoral degrees are shown separately to indicate the proportion of postgraduate degrees which are PhDs $(n=237)$.

\section{Skill Sets and Gaps}

Over the last decade, government and private sector employers in Australia have been increasingly vocal about a perceived lack or diminution of graduates' practical archaeological knowledge and skills (e.g. Colley 2004; Gibbs et al. 2005; Lydon 2002). These concerns are reflected in the survey results. Over $86 \%$ (up from $84.1 \%$ in 2005) of respondents agreed that more emphasis should be placed on developing practical consulting skills in undergraduate degrees, while $91.5 \%$ (up from $87.4 \%$ ) agreed that more emphasis should be placed on developing broad critical thinking skills in undergraduate degrees. Virtually all respondents (99.5\%, up from $98 \%$ ) also agreed or strongly agreed that practical, field-based archaeological experience should be an important part of undergraduate training in archaeology, with $82.1 \%$ (down from $86.2 \%$ ) agreeing that there is a need for a vocationally-oriented option for graduates as well as the traditional research-oriented Honours year.

Previous commentary on archaeological skills and skill gaps has been based on anecdotal evidence or largely unstructured qualitative data collected as part of teaching and learning conference and workshop sessions (e.g. Colley 2003; Gibbs et al. 2005; cf. Lydon 2002). In an attempt to address this issue explicitly, respondents were asked to rate both their personal level of experience in a range of skill areas and then to rate how valuable these skills were for archaeologists in their workplace. The 42 skill areas were divided into overlapping categories of 'Non-Archaeology Specific Skills' and 'Archaeology Specific Skills' (Table 2) and are loosely based on those identified by delegates at the Redfern Workshop as what students should learn through studying archaeology at Australian universities (Colley 2004:194; see also Beck [2008] for a discussion of skills for benchmarking

\begin{tabular}{|l|c|}
\multicolumn{1}{|c|}{ Qualification Level } & Average Salary \\
\hline No Formal & AUD $\$ 72,500$ \\
\hline Undergraduate + Honours & AUD $\$ 80,463$ \\
\hline Postgraduate (exc. Doctorate) & AUD $\$ 81,977$ \\
\hline PhD & AUD $\$ 94,268$ \\
\hline
\end{tabular}

Table 1 Average salary by highest qualification, full-time only.

of Honours degrees in Australia). The skill areas range from the specific (e.g. ceramic analysis) to the generic (e.g. critical thinking). Four new skills were added (Indigenous consultation, sediment analysis, floral analysis, cataloguing of artefacts) based on feedback from the 2005 survey.

Interpersonal communication ranked as the most valuable skill, followed closely by report writing and computer literacy (Table 3). Only two of the 10 most valued skills are considered to be archaeology specific skills (field survey techniques and knowledge of legislation), with the others representing more generic skills. The valued skills in the 2010 survey closely correspond to those identified in the 2005 survey, with minimal movement into or out of the top-10 and only minor adjustments in priority.

Skill gaps were determined by calculating an index for each respondent for each question (i.e. the gap between how valuable respondents perceived a skill to be in their workplace versus their personal level of experience). The most significant finding of this analysis was that there is no overlap between the 10 most valuable skills identified by respondents and the top- 10 skill gaps (compare Tables 3 and 4). For example, interpersonal communication was ranked first in the list of most valuable skills, but was ranked last out of the 42 skill gaps, indicating 
no perceived skill gap in this area. In contrast to the 10 most valuable skills, which tended towards more generic categories, the top-10 skill gaps tended to focus on specific skill sets, such as residue and use-wear analysis, floral analysis, GIS etc.

In general terms, when the distribution of skill gaps is considered by primary subject focus (Table 5) some clear trends are evident. For example, diving is not in the top-10 skill gaps for maritime archaeologists, presumably because most professionals already have this skill. Similarly, cross-cultural communication features in the top-10 skill gaps for historical and maritime archaeologists, but not for specialists in Indigenous archaeology, which involves frequent cross-cultural communication. Other findings are counter-intuitive at first glance, such as ceramic analysis being identified as a major skill gap for Indigenous archaeology; however, as identified above, many Indigenous archaeology professionals identified historical archaeology as a secondary area of professional practice and vice versa.
Identified skill gaps show remarkable consistency across primary subject focus. Residue and use-wear analysis, floral analysis, human skeletal identification and analysis, sediment analysis and faunal analysis are gaps for professionals working for Indigenous, historical, maritime and classical archaeology. GIS, and rock art recording and analysis are identified as skill gaps in Indigenous, historical and maritime subfields, but not for classical archaeology. These skill gaps mirror the 2005 values with two exceptions: advocacy/public relations is now identified as a skill gap only in Indigenous archaeology; and statistical analysis only in historical archaeology rather than across all subfields. The valued skills and the skill gaps identified across primary subject focus areas suggest there are core skills essential to much of the professional workforce (cf. Lydon 2002:131). These findings can inform curriculum development in universities and continuing professional education.

\begin{tabular}{|l|l|}
\hline \multicolumn{1}{|c|}{ Non-Archaeology Specific Skills } & \multicolumn{1}{c|}{ Archaeology Specific Skills } \\
\hline General business & Field survey techniques \\
\hline Interpersonal communication & Excavation techniques \\
\hline Leadership & Stone artefact identification and analysis \\
\hline Human resource management & Faunal analysis \\
\hline Occupational health and safety & Residue and use-wear analysis \\
\hline Sales/marketing & Archaeological theory \\
\hline Advocacy/public relations & Rock art recording and analysis \\
\hline Report writing & Ceramic analysis \\
\hline Library/archival research & Human skeletal identification and analysis \\
\hline Computer literacy & Knowledge of legislation \\
\hline Geographical information systems (GIS) & Significance assessment \\
\hline Statistical analysis & Heritage management planning \\
\hline Cross-cultural communication & Conservation of artefacts \\
\hline Knowledge of intellectual property issues & Policy development \\
\hline Photography & Understanding of research ethics \\
\hline Critical thinking & Drawing/illustration \\
\hline Time management & Sediment analysis* \\
\hline Project management & Floral analysis* \\
\hline Negotiation/mediation & Cataloguing of artefacts* \\
\hline Diving & \\
\hline Four-wheel driving & \\
\hline Teaching/training & \\
\hline Indigenous consultation* & \\
\hline & \\
\hline
\end{tabular}

Table 2 Skill areas used to define gaps in training (after Colley 2004; Ulm et al. 2005). *New for 2010 survey.

\begin{tabular}{|l|}
\multicolumn{1}{|c|}{ Skill } \\
\hline Interpersonal communication \\
\hline Report writing \\
\hline Computer literacy \\
\hline Time management \\
\hline Project management \\
\hline Critical thinking \\
\hline Library/archival research \\
\hline Field survey techniques \\
\hline Knowledge of legislation \\
\hline Leadership \\
\hline
\end{tabular}

Table 3 Top-10 most valuable skills (all respondents). Archaeologyspecific skills shaded.

\begin{tabular}{|l|}
\multicolumn{1}{|c|}{ Skill } \\
\hline Residue and use-wear analysis \\
\hline Floral analysis* \\
\hline Geographical information systems (GIS) \\
\hline Human skeletal identification and analysis \\
\hline Sediment analysis* \\
\hline Faunal analysis \\
\hline Rock art recording and analysis \\
\hline Statistical analysis \\
\hline Advocacy/public relations \\
\hline Conservation of artefacts \\
\hline
\end{tabular}

Table 4 Top-10 skill gaps (all respondents). Archaeology specific skills shaded. * New for 2010 survey. 
Our results contrast with the potential skill gaps identified in Aitchison and Edwards' (2008:153-155) recent study in the UK, where information technology, project management, desk-based research and artefact research were identified as priorities for training. Computer literacy, project management and library/archival research all ranked outside the top- 25 skill gaps identified here. These results point to the different character of contemporary professional archaeological workplaces in Australia and the UK.

\section{Discussion}

Results of the AAP surveys in 2005 and 2010 confirm the professional Australian archaeological landscape as a dynamic environment, with significant growth and change in the industry in the five years elapsing between surveys. Throughout we have commented on a range of these issues and here we elaborate on a few of what we consider to be the most significant trends. In commenting on trends, some are a result of the observation of relatively small proportional changes. As there are also currently only two data points, namely from the 2005 and 2010 surveys, we will need to confirm these trends with the findings of the next survey in the longitudinal study, planned for 2015. In the meantime, while indicating movement, results should be treated cautiously.

Many of the changes can be attributed to the impacts of growth in the resources sector and altered legislative requirements. The rise in the number of archaeologists based in Vic. is associated with new requirements ushered in by the Aboriginal Heritage Act 2006, while the ongoing growth in the WA resources sector is driving growth in Indigenous CHM. These changes are also reflected in the strong growth of $14.2 \%$ in Indigenous archaeology at the expense of historical and maritime archaeology, down $8.8 \%$ and $2.5 \%$, respectively. Overall the private sector has grown $4.2 \%$, while the government archaeology sector has contracted $6.8 \%$, with stasis in the university and museum sectors. When these data are taken together with the increasingly young age profile of the profession, the increase in the size of archaeological workplaces and the decrease in the number of people undertaking sustained volunteer work, the pattern suggests increasing pressure on the industry to provide graduates for employment in the private sector.

Identified skill gaps also reflect skills valued in the private sector by archaeologists engaged in CHM activities. The archaeology specific skills of residue and use-wear analysis, floral analysis, human skeletal identification and analysis, sediment analysis, faunal analysis and rock art recording, along with the non-archaeology specific skill of GIS, were identified as gaps for professionals working in Indigenous, historical and maritime. The fact that respondents are identifying these areas as skill gaps may indicate a move to a more nuanced professional landscape with more differentiation and specialisation of skills, in part reflecting an increase in the scale of archaeology as part of the move to larger workplaces between 2004 and 2009. The fact that gaps were identified in 2005 in occupational health and safety (moving from $8^{\text {th }}$ to $17^{\text {th }}$ place in 2010) and human resource management ( $9^{\text {th }}$ to $21^{\text {st }}$ place) may also reflect these changes in the industry, with these tasks undertaken by specialists in larger organisations.

The contrast between the broad generic nature of the most valued skills (mostly non-archaeology specific) (Table 3 ) and the mainly archaeology specific practical skill gaps (Table 4) support Lydon's (2002) findings that both technical and broad conceptual skills were vital to meeting current demands of the workplace as part of a broader curriculum (see also McBryde 1980). The fact that none of the skills listed as most valued (e.g. critical thinking, report writing, library/archival research, computer literacy) feature in the list of skill gaps suggests that current approaches to teaching and learning are furnishing archaeology graduates with these transferable skills. However, the technical and practical skills identified as skill gaps indicate curricula need more scaffolding to incorporate more of these skills into existing structures. As Gibbs et al. (2005) argued, teaching of these technical and practical areas is precisely what has suffered the most with changes in university funding and pressure on resources. Furthermore, Lydon's (2002:134, original emphasis) respondents identified practical

\begin{tabular}{|c|c|c|c|}
\hline Indigenous & Historical & Maritime & Classical \\
\hline $\begin{array}{l}\text { Residue and use-wear } \\
\text { analysis }\end{array}$ & GIS & Indigenous consultation & $\begin{array}{l}\text { Residue and use-wear } \\
\text { analysis }\end{array}$ \\
\hline Floral analysis & $\begin{array}{l}\text { Residue and use-wear } \\
\text { analysis }\end{array}$ & Faunal analysis & $\begin{array}{l}\text { Human skeletal identification } \\
\text { and analysis }\end{array}$ \\
\hline $\begin{array}{l}\text { Human skeletal identification } \\
\text { and analysis }\end{array}$ & Floral analysis & GIS & Floral analysis \\
\hline GIS & Indigenous consultation & $\begin{array}{l}\text { Stone artefact identification } \\
\text { and analysis }\end{array}$ & Faunal analysis \\
\hline $\begin{array}{l}\text { Rock art recording and } \\
\text { analysis }\end{array}$ & $\begin{array}{l}\text { Human skeletal identification } \\
\text { and analysis }\end{array}$ & Sediment analysis & Policy development \\
\hline Sediment analysis & Statistical analysis & $\begin{array}{l}\text { Residue and use-wear } \\
\text { analysis }\end{array}$ & Sediment analysis \\
\hline Faunal analysis & Cross-cultural communication & $\begin{array}{l}\text { Human skeletal identification } \\
\text { and analysis }\end{array}$ & $\begin{array}{l}\text { Heritage management } \\
\text { planning }\end{array}$ \\
\hline Advocacy/public relations & Sediment analysis & Floral analysis & Occupational health/safety \\
\hline Conservation of artefacts & $\begin{array}{l}\text { Rock art recording and } \\
\text { analysis }\end{array}$ & $\begin{array}{l}\text { Rock art recording and } \\
\text { analysis }\end{array}$ & Statistical analysis \\
\hline \multirow[t]{2}{*}{ Ceramic analysis } & Faunal analysis & Human resource management & Indigenous consultation \\
\hline & & Cross-cultural communication & \\
\hline
\end{tabular}

Table 5 Top 10 skill gaps by primary subject focus. Shaded cells indicate skill gaps common across all primary subject focus areas. Note that for maritime archaeology two skills were ranked equal tenth place. 
skills as those which they find useful in their work but which they acquired outside their formal university courses, and they nominated these skills as priorities for further training.

In the past, student volunteer work outside of, or parallel to, traditional university settings has been important in developing the skill sets of graduates. As Frankel (1998:25) noted, the 'multiple skills required in the field can only be learnt by practice ... [and] [s] erious archaeology students often sacrifice much in order to participate in excavations'. The reliance on learning through volunteer work presents a two-fold problem. First, the high market demand for graduates appears to be diminishing the time available for volunteer work. Second, there is clearly a need to balance the more traditional framework of obtaining practical skills while studying through volunteer laboratory and fieldwork with changes in students' economic environments, in which many work either part-time or full-time and have a range of competing responsibilities beyond university (e.g. Fredericksen 2005).

Several commentators have noted that the low staffing levels and resource constraints in Australian university archaeology departments limit their ability to offer a large range of courses (e.g. Colley 2004:190; Lydon 2002). In response to changes in the discipline, Beck and Balme (2005:33) noted that universities 'have changed their courses to include units in heritage, public archaeology and so on, but within the current degree structure there is simply no room to provide the kinds of specific training that the profession expects'. At the undergraduate level, some of the kinds of specialist skills identified here as skill gaps might require new appointments in archaeology departments where staff expertise does not exist (e.g. physical anthropology) or investment in teaching facilities (e.g. computer laboratories for GIS).

In the short-term, some of the identified skill gaps can be addressed by providing more structured guidance to undergraduate students to undertake specific elective courses in faculties beyond the humanities and social sciences (see also Gibbs et al. 2005; Lydon 2002:134). For example, GIS can be studied in geography and planning departments, human skeletal identification and analysis in anatomy, statistical analysis in mathematics etc. Although it might be desirable to design specific archaeological course content in these areas in the long-term, using existing courses would allow resources to be redirected to other more pressing areas. Basic expertise in specialised archaeological skills, such as faunal, floral and sediment analysis, residue and use-wear analysis, and rock art recording and analysis, might be usefully addressed outside the standard university context through short courses run by professional bodies or universities. Since 2005 there have been increases in the number of short professional development courses on offer on a range of topics. The number of people agreeing or strongly agreeing that there should be more short (e.g. two to five day) professional development courses on offer for archaeologists increased from 95\% in 2005 to $96.9 \%$ in 2010 , indicating continuing demand in this area.

In the absence of radically increased funding for university archaeology teaching and learning, a longer-term solution might require formalising cross-institutional enrolment opportunities. Over $94 \%$ of respondents agreed that there should be more opportunities for undergraduate students to participate in cross-institutional studies in archaeology. Formalisation and elaboration of cross-institutional crediting arrangements would take advantage of the resources and teaching expertise of different institutions, minimise duplication of resources and allow greater curriculum breadth than currently available at any single Australian institution.

\section{Conclusion}

Results of the latest iteration of the AAP survey show the changing face of Australian archaeology in the last five years. Results show significant growth in Indigenous archaeology, increasing participation of women, an increasingly young age profile and strong income growth. At the same time, the low participation rates of professionally qualified Indigenous archaeologists, the growth in the size of workplaces and the reduction in sustained volunteer work present significant challenges for the future of professional archaeology in Australia. Significantly, the increasing numbers of archaeologists in Australia working in the private sector, and the high confidence expressed for expansion of this sector, emphasises the need for archaeology teaching and learning frameworks to respond to vocational training requirements.

The data provided by the AAP survey allow insights into how archaeology conducted in and from Australia is changing. In future, these data will allow international comparisons and in the longer-term future iterations of the survey will allow the strength and impact of longitudinal trends to be assessed. Even in two surveys some interesting changes in the profession have been discernible over the last five years.

\section{Acknowledgements}

For comments and feedback on the survey instrument we thank Lynley Wallis, Karen Murphy, Sarah Colley, Richard Fullagar, Catherine Quinn, Jacqueline Matthews and Ross Anderson. For support and assistance in distributing the survey we thank the AIMA, ASHA, AAA and AACAI. Funding was provided by the ANCATL. Finally, a special thanks to the archaeologists working in and from Australia who took the time to complete the surveys. This study was approved by the UQ Behavioural and Social Sciences Ethical Review Committee (Clearance Numbers 2005000159 and 2010000166). SU is the recipient of an Australian Research Council Future Fellowship (project number FT120100656).

\section{References}

Aitchison, K. 1999 Profiling the Profession: A Survey of Archaeological Jobs in the UK. York, London and Reading: CBA, EH and IFA.

Aitchison, K. and R. Edwards 2003 Archaeology Labour Market Intelligence: Profiling the Profession 2002/03. Bradford: Cultural Heritage National Training Organisation and the IFA.

Aitchison, K. and R. Edwards 2008 Archaeology Labour Market Intelligence: Profiling the Profession 2007-08. Reading: IFA.

Ash, J. and L. Brady 2010 Membership Secretarys' report. Australian Archaeology 70:91-92.

Association Research Inc. 20052005 Salary Survey Conducted for the Society for American Archaeology in cooperation with Society for Historical Archaeology. Rockville: Association Research Inc.

Australian Bureau of Statistics 2008 Year Book Australia. Canberra: Australian Bureau of Statistics. 
Australian Bureau of Statistics 20096345.0 Labour Price Index, Australia: December Quarter. <http://www.ausstats.abs.gov.au/ausstats/meisubs.nsf/ 0/933165DE57D36603CA2576D30015A0B3/\$File/63450_dec\%202009.pdf>

Australian Bureau of Statistics 20106302.0 Average Weekly Earnings, Australia, November 2009. <http://www.abs.gov.au/AUSSTATS/abs@.nsf/ Lookup/6302.0Main+Features1Nov\%202009?OpenDocument>

Balme, J. and W. Beck (eds) 1995 Gendered Archaeology: The Second Australian Women in Archaeology Conference. Research Papers in Archaeology and Natural History 26. Canberra: Archaeology and Natural History Publications, Research School of Pacific and Asian Studies, The Australian National University.

Beck, W. 1994 Women and archaeology in Australia. In C. Claassen (ed.), Women in Archaeology, pp.210-218. Philadelphia: University of Pennsylvania Press.

Beck, W. (ed.) 2008 By Degrees: Benchmarking Archaeology Degrees in Australian Universities. Armidale: Teaching and Learning Centre, University of New England.

Beck, W. and J. Balme 2005 Benchmarking for archaeology honours degrees in Australian universities. Australian Archaeology 61:32-40.

Beck, W. and L. Head 1990 Women in Australian prehistory. Australian Feminist Studies 11:29-48.

Bowman, J. and S. Ulm 2009 Grants, gender and glass ceilings? An analysis of ARCfunded archaeology projects. Australian Archaeology 68:31-36.

Burke, H. and C. Smith 2004 The Archaeologist's Field Handbook. Crows Nest: Allen and Unwin.

Casey, M., D. Donlon, J. Hope and S. Wellfare (eds) 1998 Redefining Archaeology: Feminist Perspectives. Research Papers in Archaeology and Natural History 29. Canberra: Archaeology and Natural History Publications, Research School of Pacific and Asian Studies, The Australian National University.

Colley, S. 2002 Uncovering Australia: Archaeology, Indigenous People and the Public. Sydney: Allen and Unwin.

Colley, S. 2003 Lessons for the profession: Teaching archaeological practical work skills to university students. Australian Archaeology 57:90-97.

Colley, S. 2004 University-based archaeology teaching and learning and professionalism in Australia. World Archaeology 36(2):189-202.

du Cros, H. 2002 Much More than Stones and Bones: Australian Archaeology in the Late Twentieth Century. Carlton South: Melbourne University Press.

du Cros, H. and L. Smith (eds) 1993 Women in Archaeology: A Feminist Critique. Occasional Papers in Prehistory 23. Canberra: Department of Prehistory, Research School of Pacific Studies, The Australian National University.

Everill, P. 2009 The Invisible Diggers: A Study of British Commercial Archaeology. Oxford: Oxbow Books.

Feary, S. 1994 Teaching and research in archaeology: Some statistics. Australian Archaeology 39:130-132.
Frankel, D. (ed.) 1980 Education and training in prehistory and archaeology in Australia. Australian Archaeology 11:69-184.

Frankel, D. 1998 Archaeology. In Anon. (ed.), Knowing Ourselves and Others: The Humanities in Australia into the 21st Century, Vol. 2, pp.17-28. Canberra: Department of Education, Employment, Training and Youth Affairs.

Fredericksen, C. 2005 Archaeology out of the classroom: Some observations from the Fannie Bay Gaol field school, Darwin. Australian Archaeology 61:41-47.

Gibbs, M., D. Roe and D. Gojak 2005 Useless graduates? Why do we all think that something has gone wrong with Australian archaeological training? Australian Archaeology 61:24-31.

Hope, J. 1993 Double bind: Women archaeologists in the New South Wales National Parks and Wildlife Service. In H. du Cros and L. Smith (eds), Women in Archaeology: A Feminist Critique, pp.175-190. Occasional Papers in Prehistory 23. Canberra: Department of Prehistory, Research School of Pacific Studies, The Australian National University,

Lydon, J. 2002 Archaeology in the workplace: Teaching about the past in a changing world. In S. Ulm, C. Westcott, J. Reid, A. Ross, I. Lilley, J. Prangnell and L. Kirkwood (eds), Barriers, Borders, Boundaries: Proceedings of the 2001 Australian Archaeological Association Annual Conference, pp.129-135. Tempus 7. Brisbane: Anthropology Museum, University of Queensland.

Martin, D.F. 2004 Capacity of Anthropologists in Native Title Practice: Report to the National Native Title Tribunal. Canberra: Anthropos Consulting Services.

McBryde, I. 1980 Educational goals of university schools of prehistory and archaeology: Mechanick trades in the ivory tower? Australian Archaeology 11:72-80.

Perry, N. 2010 Indigenous archaeologists launch new group. $<$ http://news.ninemsn. com.au/national/8180585/indigenous-archaeologists-launch-new-group $>$

Smith, C. and H. Burke 2006 Glass ceilings, glass parasols and Australian academic archaeology. Australian Archaeology 62:13-25.

Stevens, A. 2005 Membership Secretary's report. Australian Archaeology 60:88.

Truscott, M.C. and L. Smith 1993 Some descriptive statistics of permanent employment in Australian archaeology. In H. du Cros and L. Smith (eds), Women in Archaeology: A Feminist Critique, pp.217-221. Occasional Papers in Prehistory 23. Canberra: Department of Prehistory, Research School of Pacific Studies, The Australian National University,

Ulm, S., S. Nichols and C. Dalley 2005 Mapping the shape of contemporary Australian archaeology: Implications for archaeology teaching and learning. Australian Archaeology 61:11-23.

Zeder, M.A. 1997 The American Archaeologist: A Profile. Walnut Creek: Altamira Press. 